Dicle University Journal of Engineering (DUJE)

web: http://dergipark.gov.tr/dumf

Araştırma Makalesi / Research Article

\title{
Silika Aerojel Katkılı Hibrit Silis Dumanı Harçlarının Mekanik, Por Yapısı, Termal İletkenlik ve Mikro Yapı Özellikleri
}

\section{Mechanical, Pore Structure, Thermal Conductivity and Microstructure Properties of Silica Aerogel-Incorporated Hybrid Silica Fume Mortars}

\section{Levent Bostanci ${ }^{*}$}

${ }^{1}$ Beykent Üniversitesi, İnşaat Teknolojisi Programı, İstanbul, leventbostanci@beykent.edu.tr

\begin{tabular}{|c|c|}
\hline MAKALE BİLGİLERİ & ÖZET \\
\hline Makale geçmişi: & \multirow{6}{*}{ 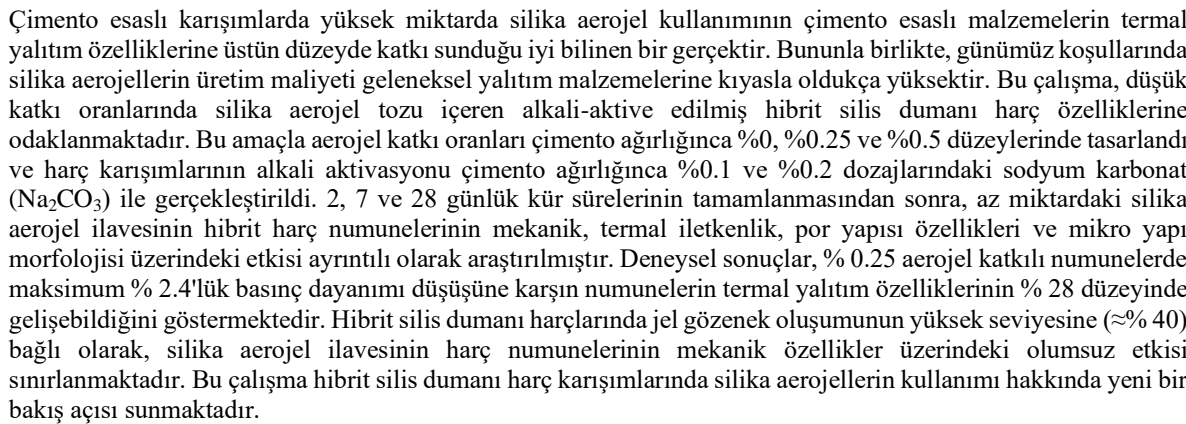 } \\
\hline Geliş: 18 Haziran 2020 & \\
\hline Düzeltme: 10 Ocak 2021 & \\
\hline Kabul: 11 Ocak 2021 & \\
\hline Anahtar kelimeler: & \\
\hline $\begin{array}{l}\text { Hibrit harç, silika aerojel, termal } \\
\text { iletkenlik, silis dumanı, por yapısı. }\end{array}$ & \\
\hline
\end{tabular}

Doi: $10.24012 /$ dumf.754876

\begin{tabular}{|c|c|}
\hline ARTICLE INFO & ABSTRACT \\
\hline & \multirow{6}{*}{$\begin{array}{l}\text { It is a well-known fact that the use of a high amount of silica aerogel in cement-based mixtures contributes } \\
\text { significantly to the thermal insulation properties of cement-based materials. However, the current manufacturing } \\
\text { cost of silica aerogels is quite expensive compared to traditional insulating materials. This study focuses on the } \\
\text { properties of alkali-activated hybrid silica fume mixtures containing silica aerogel powder at a low content rate. } \\
\text { For this purpose, aerogel inclusion ratios were designed at } 0 \%, 0.25 \% \text { and } 0.5 \% \text { by weight of binder and the } \\
\text { alkaline activation of the mortar mixtures was carried out with sodium carbonate }\left(\mathrm{Na}_{2} \mathrm{CO}_{3}\right) \text { at dosage rates of } 0.1 \% \\
\text { and } 0.2 \% \text {, by weight of binder. After } 2,7 \text { and } 28 \text { days of curing, the effect of the inclusion of a small amount of } \\
\text { silica aerogel powder on the mechanical, thermal conductivity, pore structure properties and microstructure } \\
\text { morphology of the hybrid silica fume mortar samples were investigated in detail. Experimental results show that } \\
\text { the thermal insulation properties of the samples can be improved by } 28 \% \text { with a maximum compressive strength } \\
\text { reduction of } 2.4 \% \text { in } 0.25 \% \text { aerogel-Incorporated samples. Due to the high level of gel pore formation }(\approx 40 \%) \text { in } \\
\text { hybrid silica fume mortars, the negative effect of silica aerogel addition on the mechanical properties of the } \\
\text { samples is limited. This study provides a new perspective on the use of silica aerogels in hybrid silica fume mortar } \\
\text { mixtures. }\end{array}$} \\
\hline Received: 18 June 2020 & \\
\hline Revised: 10 January 2021 & \\
\hline Accepted: 11 January 2021 & \\
\hline Keywords: & \\
\hline $\begin{array}{l}\text { Hybrid mortar, silica aerogel, } \\
\text { thermal conductivity, silica } \\
\text { fume, pore structure. }\end{array}$ & \\
\hline
\end{tabular}

* Sorumlu yazar / Correspondence

Levent BOSTANCI

$\triangle$ leventbostanci@beykent.du.tr 


\section{Giriș}

Çimento üretimi için kil ve kireçtaşının temel hammadeler olarak kalsinasyonu zorunlu olmakla birlikte kalsinasyon işlemi önemli miktarda karbondioksit $\left(\mathrm{CO}_{2}\right)$ salınımına yol açmaktadır. Son yıllarda, $\mathrm{CO}_{2}$ salınımını azaltan teknolojiler geliştirilmesine rağmen, çimento üretimi hala dünya çapındaki $\mathrm{CO}_{2}$ emisyonlarının tek bașına \%6'sından sorumludur [1]. Bununla birlikte, doğadaki mevcut kil ve kireçtaşı stoğu da klinker üretimi için çimento endüstrisi tarafından her geçen gün tüketilmektedir [2-4]. Günümüzdeki enerji verimliliği ve sürdürülebilirlik politikaları, bağlayıcı malzeme endüstrisinde geleneksel bağlayıcı malzeme olan çimentoya kıyasla endüstriyel bağlayıcı malzemelerin kullanımını teşvik etmektedir. Yüksek fırın cürufu, silis dumanı ve uçucu kül, çimento endüstrisinde endüstriyel yan ürün kökenli atık türü bağlayıcılar olarak yaygın olarak kullanılabilmektedir. Atık türü bağlayıcılar arasında silis dumanı kalsiyum-silikat yapısına olan üstün katkıları nedeniyle diğer atık türü bağlayıcılara kıyasla oldukça dikkat çekicidir [5].

Silis dumanının, kalsiyum - silikat yapısındaki mikro dolgu özelliği sayesinde, özellikle hidrasyonun ilk günlerinde daha düşük gözenekliliğe sahip bir mikro yap1 elde edilebilmektedir. Genel olarak, silis dumanı partikülleri çimento partiküllerine kıyasla $10 \mathrm{~kat}$ daha ince parçacıklardan olumaktadır, bu da daha hızlı kimyasal reaksiyona ve daha yüksek düzeyde mekanik özelliklere olanak sağlar [6,7]. Hidratasyon esnasındaki kalsiyum hidroksit (CH) tüketimi genellikle silis dumanının kimyasal reaksiyonlardaki aktivasyon yeteneğini göstermektedir. Zelic ve ark.[8] hibrit bağlayıcılı karışımlarda silis dumanının hidrasyon kinetiği üzerindeki etkisini araştırmışlardır. Çalıșmadan elde edilen sonuçlar, silis dumanının puzzolanik aktivitesinin özellikle ilk 3 günlük kür süresinin tamamlanmasından sonra dikkat çekici olduğunu göstermiştir. Hidratasyon ilerledikçe, silis dumanının $\mathrm{CH}$ ile olan aktivasyonu neticesinde dayanıma katkı sunan ilave kalsiyum-silikathidrat (C-S-H) jeli oluşabilmektedir [9].
Enerji tasarrufu ve sürdürülebilirlik politikaları ile uyumlu olarak çimento matrisinde atık türü bağlayıcıların kısmi olarak çimento ile birlikte kullanımı önem arz etmekle birlikte enerji verimliliği açısından dikkate alınması gereken hususlardan biri de yapilarda mevcut 1s1 yalitım özelliklerinin geliştirilmesidir [10]. Binalar, dünya genelinde toplam yıllık enerji tüketiminin \%40'indan tek başına sorumludur ve pratik olarak malzemelerde 1sı yalıtım özelliklerinin geliștirilmesi için önemli bir çaba harcanması gerektiği açıktır [11].Günümüzdeki mevcut çalışmalar, alkali-aktive edilmiş karışımlar ile 1s1l yalıtım özelliği yüksek malzemelerin bir araya getirildiği kompozitler üzerine odaklanmaktadır [12].Yakın geçmişte yapılan deneysel çalışmalar nano-teknolojik ısı yalıtım malzemelerinin çimento matrisinde kullanımının potansiyelini işaret etmekle birlikte silika aerojeller üstün yalıtım özellikleri ve çimento matrisi ile olan uyumları dikkate alındığında çimento esaslı malzemler ile birlikte kullanım açısından oldukça dikkat çekmektedir $[13,14]$.

Silika aerojeller, ilk kez 1930'larda S. Kistler tarafından üretilmiştir [15]. Başlangıçta otomotiv, elektronik, giyim, kimya gibi farkl1 sektörlerde kullanılan silika aerojeller sonraki dönemlerde üstün yalıtım özellikleri nedeniyle çimento esaslı yap1 malzemesi üretiminde de kullanım alanı bulmaya başlamıșlardır [16,17]. Silika aerojeller, $500-1200 \mathrm{~m}^{2} /$ g'lik yüksek yüzey alanları, $0.003 \mathrm{~g} / \mathrm{cm} 3$ 'lük düşük yoğunlukları, \%99.8' varan yüksek poroziteleri ve $0.005 \mathrm{~W} /(\mathrm{m} . \mathrm{K})$ 'llk oldukça düşük termal iletkenlik katsayıları ile dünyanın en hafif katısı olarak tanımlanabilmektedir $[18,19]$.

Literatürde yer alan çalışmalar, yüksek üretim maliyetlerine karşın çimento esaslı malzemelerde genellikle yüksek katk1 oranlarında silika aerojel kullanımına odaklanıldığını göstermektedir. Ayrıca, silika aerojel katk1lı- çimento esaslı malzemelerin 1s1 yalıtım performansı ile ilgili çalışmaların çoğu yüksek 1s1 yalıtımı-düşük basınç dayanımı ilişkisine odaklanmıştır. Ng ve diğ. [20] hacimce \%80'e kadar aerojel içeren harç karışımları hazırladilar. Deneysel sonuçlar, hacimce \%50 aerojel içeren karışımlarda $20 \mathrm{MPa}$ 'lık bir basınç 
dayanımı ile $0.55 \mathrm{~W} /(\mathrm{m} . \mathrm{K})$ termal iletkenlik değerinin saptanabileceğini göstermiştir. Aerojel partikülleri ve çimento matrisi arasındaki ara yüzey geçiş bölgesindeki zayıf etkileşimi arttırmak için yeni bir karıştırma prosedürü geliştirilmesi önerilmiştir. Liu ve diğ. [21] harç karışımlarındaki standart kumu \%60 seviyesine kadar silika aerojel ile yer değiştirmiştir. \%60 aerojel içeriğinde, numunelerde 0.1524 W/(m.K)'lık termal iletkenlik katsayısına karşın 2.15 MPa'lık basınç dayanımı saptanmıştır. Yapılan deneylerde, modifiye edilmiş $\mathrm{SiO}_{2}$ aerojel partiküllerinin, modifiye edilmemiş $\mathrm{SiO}_{2}$ aerojel partiküllerine kıyasla çimento matrisi ile daha iyi bir bağlanma mekanizması gösterdiği vurgulanmıştır. Wang ve diğ. [19] oluşturdukları karışımlardaki kumu \%100'e kadar bir düzeyde agrega olarak aerojel ile doldurulmuş perlit ile değiştirmiştir. Agrega olarak \%100 aerojel içeren karışım numunelerinde, $0.071 \mathrm{~W} /(\mathrm{mK})$ termal iletkenlik değeri ve $3.71 \mathrm{MPa}$ basınç dayanımı tespit edilmiştir. Çalışmadan elde edilen sonuçlar, aerojel etkisinin $0.5 \mathrm{su} /$ bağlayıcı oranında dikkat çekici olduğunu göstermiştir. Silika aerojellerin çimento içeriği azaltılmış hibrit bağlayıcılı harçlarda kullanımı da oldukça başarılı sonuçlar verebilmektedir. Harç karışımlarına $\% 60$ düzeyinde kum ile yer değiştirilmek suretiyle eklenen silika aerojeller vasıtasıyla uçucu kül içerikli hibrit harç numunelerinde $26.78 \mathrm{MPa}$ 'lı basınç dayanımı ve 5.48 MPa'lık eğilme dayanımı değerlerine karşın $0.918 \mathrm{~W} /(\mathrm{m} . \mathrm{K})$ düzeyinde termal iletkenlik katsayısı elde edilebilmektedir [22].

Öte yandan, sınırlı sayıdaki deneysel çalışmada düşük miktardaki silika aerojel içeriğinin numunelerin mekanik ve termal yalitım performanslarına olan etkisi araştırılmıştır. Kim ve diğ. [16] \%2.0 düzeyine kadar silika aerojel içeren çimento karışımları hazırladılar. \%0.5 silika aerojel katkılı numunelerde, $0.4 \mathrm{~W} /(\mathrm{m} . \mathrm{K})$ termal iletkenlik değeri ile birlikte $13.1 \mathrm{MPa}$ düzeyinde basınç dayanımı saptanmıştır. Çalışmanın sonuçları, aerojel içeriği ile termal yalıtım özellikleri arasında doğrusal bir ilişki olduğunu göstermiştir. Bostancı ve Sola [12] bağlayıcı malzeme ağırlığınca $\% 0.75$ ve $\% 1.0$ düzeylerinde silika aerojel içeren cüruf harcı karışımları hazırladılar. \%0.75 aerojel katkılı alkali-aktive edilmiş cüruf harcı numunelerinde 34.1 MPa basınç dayanımı değerine karşın termal iletkenlik katsayısı değeri $1.32 \mathrm{~W} /(\mathrm{m} . \mathrm{K})$ düzeyinde tespit edilmiştir. Deneysel sonuçlar, silika aerojel katkısı aracılığı ile gözenekliliği artan por yapısı nedeniyle termal iletkenlik katsayısında önemli bir azalmanın elde edilebileceğini göstermiştir.

$\mathrm{Bu}$ araştırmanın odak noktası, düşük katkı oranlarındaki silika aerojel ilavesinin harç numunelerinin mekanik, termal iletkenlik, por yapısı özellikleri ve mikro yapı morfolojisi üzerindeki etkisini araştırmaktır. Literatür, yüksek düzeyde silika aerojel içeren karışımlara kıyasla düşük katkı oranlarında silika aerojel içeren karışımların özellikleri hakkında çok az veri bulunduğunu göstermektedir. Silika aerojellerin karışımlarda kum ile yer değiştirilerek kullanıldığg durumlarda meydana gelen yüksek düzeydeki termal yalıtkanlık artışının dramatik düzeyde mekanik dayanım düşüşlerine yol açtığı bilinmektedir. Bununla birlikte, silika aerojelin çimento katkı maddesi olarak kullanımı için mekanik özellikler ile termal iletkenlik katsayısının değişimi yeterince araştırılmamıştır. Araştırmanın bir diğer yenilikçi yönü, silika aerojel kullanımının çimento karışımları yerine hibrit harç karışımlarında incelenmesidir.

\section{Malzeme ve Yöntem}

\section{Kullanilan Malzemeler}

\section{Bağlayici Malzemeler}

Deneysel çalışmalar kapsamında bağlayıcı malzeme olarak TS EN 197 - 1[23] standard esaslarına uygun olarak üretilmiş CEM I $42.5 \mathrm{R}$ tipi çimento ve silis dumanından oluşan karma bağlayıcı malzeme kullanılmıştır. Tablo 1'de kullanılan çimento ve silis dumanına ait kimyasal kompozisyon ve fiziksel özellikler görülmektedir. 
Tablo 1. Kullanılan bağlayıcı malzemelerin

kimyasal kompozisyonu ve fiziksel özellikleri

\begin{tabular}{|c|c|c|}
\hline & Çimento & $\begin{array}{c}\text { Silis } \\
\text { dumanı }\end{array}$ \\
\hline \multicolumn{2}{|c|}{ Kimyasal kompozisyon $(\%)$} \\
\hline $\mathrm{SiO}_{2}$ & 20.14 & 93.29 \\
\hline $\mathrm{Al}_{2} \mathrm{O}_{3}$ & 4.92 & 0.48 \\
\hline $\mathrm{Fe}_{2} \mathrm{O}_{3}$ & 3.04 & 1.27 \\
\hline $\mathrm{CaO}$ & 63.03 & 0.54 \\
\hline $\mathrm{MgO}$ & 1.18 & 0.32 \\
\hline $\mathrm{SO}_{3}$ & 2.94 & 0.1 \\
\hline $\mathrm{K}_{2} \mathrm{O}$ & 0.73 & 0.89 \\
\hline $\mathrm{Na}_{2} \mathrm{O}$ & 0.16 & 0.27 \\
\hline $\mathrm{Cl}^{-}$ & 0.01 & - \\
\hline \multicolumn{3}{|c|}{ Fiziksel özellikler } \\
\hline Özgül ağırlık & 3.12 & 2.31 \\
\hline $\begin{array}{c}\text { Yüzey alanı } \\
\left(\mathrm{m}^{2} / \mathrm{kg}\right)\end{array}$ & 380,4 & 23,336 \\
\hline
\end{tabular}

\section{Kum}

Harç karışımlarında TS-EN 196-1 [24] standardı esaslarına uygun olarak Limak Trakya çimento fabrikasında üretilmiș olan standart Rilem kumu kullanılmıştır. Kullanılan kum için saptanan yoğunluk ve doygun-yüzey kuru özgül ağırlık değerleri sirasiyla $1.35 \mathrm{~kg} / \mathrm{dm}^{3}$ ve 2.63 'tür.

\section{Alkali Aktivatör}

Harç karışımlarında alkali aktivatör olarak sodyum karbonat $\left(\mathrm{Na}_{2} \mathrm{CO}_{3}\right)$ kullanılmıştır. Tablo 2'de kullanılan $\mathrm{Na}_{2} \mathrm{CO}_{3}$ 'e ait kimyasal kompozisyon görülmektedir.

Tablo 2. $\mathrm{Na}_{2} \mathrm{CO}_{3}$ kimyasal kompozisyonu.

\begin{tabular}{|c|c|}
\hline \multicolumn{2}{|c|}{ Kimyasal kompozisyon } \\
\hline $\mathrm{Na}_{2} \mathrm{CO}_{3}(\%)$ & $>99.5$ \\
\hline $\mathrm{NaCl}_{2}(\%)$ & $<0.1$ \\
\hline $\mathrm{Na}_{2} \mathrm{SO}_{4}(\%)$ & $<0.1$ \\
\hline
\end{tabular}

\section{Silika Aerojel}

Harç karışımlarında toz formda silika aerojel kullanılmıştır. Silika aerojel sipariş üzerine ENSATE Yalıtım Teknolojileri tarafından hazırlanmıştır. Tablo 3'de kullanılan silika aerojel'e ait özellikler görülmektedir.

Tablo 3. Kullanılan silika aerojelin özellikleri.

\begin{tabular}{|c|c|}
\hline Yüzey alanı $\left(\mathrm{m}^{2} / \mathrm{g}\right)$ & $790-840$ \\
\hline Por çap1 $(\mathrm{nm})$ & $8-10$ \\
\hline Porozite $(\%)$ & $>\% 94$ \\
\hline $\begin{array}{c}\text { Görünür yoğunluk } \\
\left(\mathrm{kg} / \mathrm{m}^{3}\right)\end{array}$ & $90-100$ \\
\hline Yüzey grubu & $-\mathrm{OH}$ \\
\hline
\end{tabular}

\section{Karışım Oranları}

Hibrit silis dumanı harç karışımlarına düşük katkı oranlarında ilave edilen silika aerojel katkısının harç numunelerinin mekanik, termal iletkenlik, por yapısı ve mikro yapı özelliklerine olan etkisini araştırmak amacıyla 5 farklı harç karışımı hazırlanmıştır. Her karışımdan üçer adet harç numunesi üretilmiştir. Karışımlar, su/ bağlayıcı oranları 0.5 olacak şekilde ayarlanmışlardır. Oluşturulan harç karışımlarında iki farklı dozajda alkali aktivatör ve iki farklı katkı oranında silika aerojel katkısı bağlayıcı malzeme ağırlığınca karışımlara ilave edilmiştir. Harç karışımları oluşturulurken gerek silika aerojel katkısının gerekse aktivatör dozajının düşük oranlarda kullanılması planlanmıştır. Tablo 4' de üretilen harç numunelerine ait karışım oranları görülmektedir. 
Tablo 4. Karışım oranları.

\begin{tabular}{|c|c|c|c|c|c|c|c|}
\hline Karışım & $\begin{array}{c}\text { Aerojel } \\
\text { (g) }\end{array}$ & $\begin{array}{c}\mathrm{Na}_{2} \mathrm{CO}_{3} \\
(\mathrm{~g})\end{array}$ & $\begin{array}{c}\text { Silis } \\
\text { dumanı } \\
\text { (g) }\end{array}$ & $\begin{array}{c}\text { Çimento } \\
\text { (g) }\end{array}$ & Su/bağlayıcı & $\begin{array}{c}\mathrm{Su} \\
(\mathrm{ml})\end{array}$ & $\begin{array}{c}\text { Kum } \\
(\mathrm{g})\end{array}$ \\
\hline S1 & 0 & 0.45 & \multirow{5}{*}{225} & \multirow{5}{*}{225} & \multirow{5}{*}{0.5} & \multirow{5}{*}{225} & \multirow{5}{*}{1350} \\
\hline S2 & 1.125 & 0.45 & & & & & \\
\hline S3 & 1.125 & 0.9 & & & & & \\
\hline S4 & 2.25 & 0.45 & & & & & \\
\hline S5 & 2.25 & 0.9 & & & & & \\
\hline
\end{tabular}

\section{Numune Hazırlanması, Kür Koşulları Ve Uygulanan Testler}

Deneysel çalışmalar kapsamında 40x40x160 mm ölçülerinde tek tip prizmatik harç numuneleri üretilmiştir. Deneylerde kullanılan silika aerojel partiküllerinin karışımlardaki homojenliğini sağlamak amacıyla başlangıçta kuru bir karıştırma işlemi uygulanmıştır. Karışımlara su ilavesi azar azar yapılmış ve aerojel partiküllerinin bağlayıcı malzeme ile tamamen kaplanmasına özellikle dikkat edilmiştir.

Üretilen harç numuneleri oda sicaklığında 24 saat kalıpta bekletildikten sonra kalıptan çıkarılmış ve 2,7 ve 28 günlük farklı kür süreleri için laboratuvar ortamında $\left(20 \pm 3 \quad \mathrm{C}^{\circ}\right)$ sıcaklığındaki kür havuzunda daldırılmak suretiyle tutulmuştur. Kür süresi gelen harç numuneleri sırasıyla eğilme dayanımı, basınç dayanımı, termal iletkenlik katsayısı ölçümü, mikro yap1 analizi ve por yapısı analizi testlerine tabi tutulmuşlardır. Mekanik dayanım testleri 2,7 ve 28 günlük kür süresini tamamlayan tüm numunelere uygulanırken termal iletkenlik katsayısı ölçümü, mikro yapı analizi ve por yapısı analizi testleri sadece 28 günlük harç numunelerine uygulanmıştır. Şekil 1'de uygulanan test programı görülmektedir.

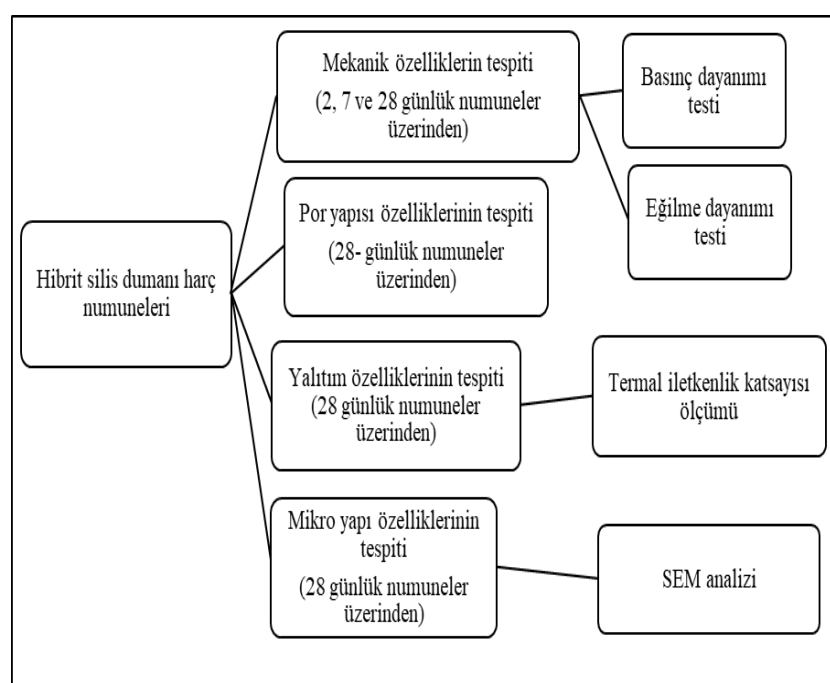

Şekil 1.Test programı

Kür süresini tamamlayan harç numunelerine ilk olarak 3 noktalı eğilme testi uygulanmıştır. Eğilme dayanımı testi TS EN 1015-11 [25] standartı esaslarına göre gerçekleştirilmiştir. Eğilme testinin uygulanması esnasında yükleme hızı $50 \pm 10 \mathrm{~N} / \mathrm{s}$ ayarlanmış ve yükleme esnasında orta açıklık $100 \mathrm{~mm}$ olacak şekilde eğilme testi gerçekleştirilmiştir. Her bir karışıma ait 3 farklı numuneye eğilme testi ayrı ayrı uygulanmış ve üç farklı numune için aritmetik ortalama alınarak karışımın eğilme dayanımı tespit edilmiştir.

Eğilme dayanımı testi sonrasında ikiye ayrılan numuneler muhafaza edilerek her bir karışıma ait 3 farklı numuneden elde edilmiş 6 farklı numune parçasına basınç dayanımı testi uygulanmıştır. $\mathrm{Bu}$ sayede karışımın basınç dayanımı, toplam 6 adet test sonucunun ortalaması olarak tespit 
edilebilmiştir. Basınç dayanımı testi, 40x40 mm yüzey alanlı numune parçaları üzerinden gerçekleştirilmiştir. Mekanik dayanım testlerinin tamamlanmasının ardından geriye kalan numune parçaları üzerinden termal iletkenlik katsayısı ölçümü, mikro yapı analizi ve por yapısı analizi testleri gerçekleştirilebilmiştir.

Termal iletkenlik katsayısı ölçümü TCI- Thermal Conducttivity Analyzer model cihaz ile gerçekleştirilmiştir. Cihaz hassas sensoru sayesinde minimum $3 \mathrm{~cm}$ çapa sahip numunelerin termal iletkenlik katsayılarını ölçebilmektedir. Termal iletkenlik testi esnasında ölçüm işleminin hassasiyeti için numune parçalarının yüzey düzgünlüğü ve pürüzsüzlüğüne özellikle dikkat edilmiştir. İletkenlik katsayısı ölçümü, numunelerin farklı bölgeleri için $5 \mathrm{kez}$ tekrarlanmış ve farklı bölgelerden elde edilen ölçüm sonuçlarının aritmetik ortalaması alınarak harç numunelerinin termal iletkenlik katsayıları tespit edilmiştir.

Numune parçaları üzerinden hasarsız olarak gerçekleştirilen termal iletkenlik katsayısı ölçümünün ardından aynı numune parçalarına por yapısı özelliklerinin tespiti için cıva porozimetresi testi uygulanmıştır. Cıva porozimetresi testi ile harç numunelerine ait toplam porozite, por çap1 boyutları ve çap dağılımları gibi por yapısı özellikleri tespit edilebilmiştir. Civa Porozimetresi deneyi, Micromeritics marka cihaz ile gerçekleştirilmiştir. Cihaz ile 3 - 360,000 nanometre $(\mathrm{nm})$ aralığındaki por çapları tespit edilebilmektedir.

Civa porozimetresi analizine benzer şekilde 28 günlük basınç dayanımı testinden geriye kalan numune parçaları üzerinden mikro yap1 özelliklerinin tespiti amaciyla SEM analizi gerçekleştirilmiştir. Basınç dayanımı testinde oluşan kırılma yüzeyi üzerinden hassas olarak alınan toz halindeki numune parçaları karbon ile kaplanarak mikro yapı analizine uygun hale getirilmiştir. SEM analizleri LEO 1430 VP model SEM cihazı ile gerçekleştirilmiştir.

\section{Deneysel Bulgular ve Tartışmalar}

\section{Basinç Dayanimi Test Sonuçlari}

Şekil 2'de 2, 7 ve 28 günlük kür süresinin tamamlanmasının ardından hibrit harç numunelerinde saptanan basınç dayanımı sonuçları görülmektedir.

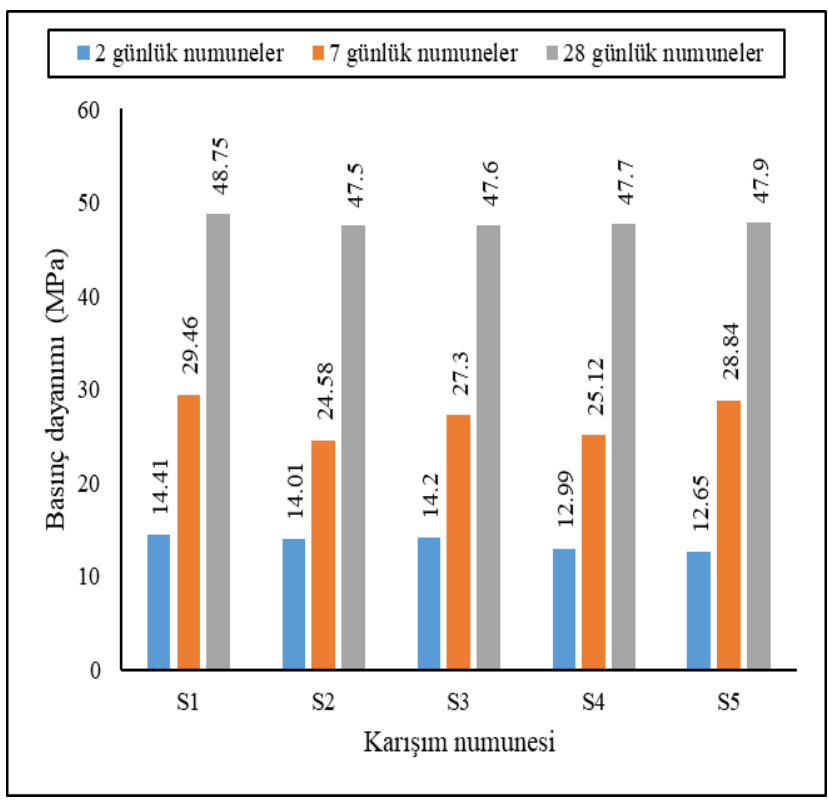

Şekil 2. 2, 7 ve 28 günlük numunelerde basınç dayanımı test sonuçları

Şekil 2'de görüldüğü gibi, kontrol harcı 2 günlükken $14.41 \mathrm{MPa} l ı k$ basınç dayanımına ulaşmıştır. Genel olarak, harç karışımlarındaki aerojel miktarı arttıkça harç numunelerinin basınç dayanımları azalmıştır. Karışımlara ilave edilen $\% 0.25^{\prime}$ lik aerojel katkısı nedeniyle S2 ve S3 harç örneklerinin 2 günlük basınç dayanımları kontrol örneğinden sirasiyla \%2.77 ve \%1.45 daha düşüktür. Karışımlara $\% 0.5$ oranında aerojel eklendiğinde de de harç numunelerinin basınç dayanımlarında benzer eğilimler gözlenmiştir. S4 ve S5 numunelerinin basınç dayanımlarında, S1 örneğine kıyasla, sırasıyla \%9.85 ve \%12.21 düzeyinde düşüşler tespit edilmiştir. Aerojel parçacıklarının çimentonun hidrastasyonu esnasında stabil kaldığı iyi bilinen bir gerçektir [21]. $\mathrm{Bu}$ noktada, kimyasal reaksiyonlara katılmayan serbest aerojel partiküllerinin harç por yapıs1 özelliklerini önemli ölçüde etkileyebileceği söylenebilir. Por yapısında yer alan boşluklar, hidratasyon ürünleri yeterince doldurulmadığında dayanımlarda düşüşlere neden olabilmektedir. Öte yandan, aerojel içeriği 
kontrol durumuna kıyasla daha düşük basınç dayanımlarına yol açmış olsa da \%0.5 aerojel içeriğine kıyasla \%0.25'lik aerojel içeriğinde dayanım düşüşleri oldukça sınırlı düzeydedir.

Alkali-aktive edilen kalsiyum-silikat yapısında, aktivatör dozajındaki artış nedeniyle basınç dayanımları da genellikle artış eğilimindedir [26].2 günlük kür süresinin tamamlanması ile elde edilen sonuçlar, aktivatör dozajındaki artış nedeniyle gelişen basınç dayanımlarının, özellikle sınırlı dayanım düşüşlerinin saptandığı $\% 0.25$ aerojel içeriğinde saptanabileceğini ortaya koymaktadır. Bu sebeple; S3 numunesinde, S2 numunesine kıyasla kısmi bir dayanım artışı elde edilirken daha yüksek aerojel içeriğinde, artan aktivatör dozajının basınç mukavemeti üzerindeki olası pozitif etkisi tespit edilememiştir (S4 ve S5 numuneleri). Ayrica, artan aerojel içeriğinin basınç mukavemeti üzerindeki negatif etkisi, artan aktivatör dozajının dayanım üzerindeki pozitif etkisine kıyasla daha baskındır. Bu nedenle, S4-S5 numunelerinde dayanım artışı gözlemlenememiştir. Buradaki en olası mekanizma, artan aerojel katkısı nedeniyle hidratasyonun ilk günlerinde daha yavaş hızda seyreden reaksiyonlar neticesinde harç gözenek yapısında oluşan ve hidratasyon ürünleri ile doldurulamayan aşırı por içeriğine atfedilebilir.

7 günlük numunelerde, 2 günlük kür süresi sonunda tespit edilen dayanım sonuçları ile uyumlu olarak silika aerojel içeren tüm numunelerin 7 günlük basınç dayanımları, kontrol örneğinden daha düşük seviyede tespit edilmiştir. S2 ve S3 harç numunelerinin basınç mukavemetleri, kontrol numunesinden sirasiyla $\% 16.56$ ve $\% 7.33$ düzeylerinde daha düşüktü. Bununla birlikte, aerojel katk1 oranındaki $\% 0.25$ 'ten $\% 0.5$ 'e olan artış, eşit aktivatör dozaj1 altında $\mathrm{S} 4$ ve S5 numunelerinin dayanımlarında $\mathrm{S} 2$ ve $\mathrm{S} 3$ numunelerine kiyasla sirasiyla $\% 2.2$ ve \%5.64 düzeylerinde artışlara neden olmuştur. Dayanım artışları sınırlı düzeyde olsa da deneysel sonuçlar, artan aktivatör dozajına kıyasla artan silika aerojel katkısının dayanım üzerindeki negatif etkisinin, hidratasyonun ilk günleri ile sınırlı olduğunu göstermektedir. Bu nedenle, daha yüksek aerojel içeriğine rağmen, artan aktivatör dozajı sayesinde daha yüksek basınç mukavemetleri elde edilebilmiştir. Öte yandan, 2 günlük numunelerde gözlemlenen belirsiz eğilimin aksine, 7 günlük basınç dayanımı sonuçları artan aktivatör dozajları ile uyum içindedir. Aktivatör dozajındaki artış, harç numunelerinin basınç dayanımlarında artışlara olanak sağlayabilmektedir. Eşit aerojel katk1 oranında artan aktivatör dozajı sayesinde S3 ve S5 numunelerinin basınç dayanımlarında $\mathrm{S} 2$ ve S4 numunelerine kiyasla sirasiyla \%11.06 ve $\% 14.8$ düzeylerinde artışlar saptanmıştır. Buradaki en olası mekanizma, artan aktivatör dozajının dayanım üzerinde olumlu etki gösteren ilave C-S-H bağları oluşturma potansiyeline atfedilebilir [12].

28 günlük numunelerdeki basınç dayanımları incelendiğinde ise, aerojel içeren tüm numunelerin dayanım gelişiminin 28 günlük kontrol örneğine benzer düzeyde olduğu gözlenmiştir. Kontrol harcında $48.75 \mathrm{MPa}^{\prime}$ l1k bir basınç dayanımı saptanırken S2 ve S3 harç numunelerinin 28 günlük basınç dayanımları, kontrol numunesinden sirasiyla $\% 2.56$ ve $\% 2.35$ düzeylerinde daha düşüktür. $\% 0.5$ aerojel katkısı içeren numunelerde de benzer eğilimler gözlenmektedir. S1 numunesine k1yasla S4 ve S5 numunelerinin basınç dayanımlarında $\% 2.15$ ve \%1.74 düzeylerinde kısmi düşüşler tespit edilmiştir. Daha önce tartışıldığı gibi, hidratasyonun ilk günlerinde özellikle $\% 0.5$ aerojel katkılı numunelerde \%12 düzeyinde bir basınç mukavemeti düşüşüne neden olan silika aerojel içeriği, 28 günlük numunelerde hidratasyonun ilk günlerine kıyasla önemli ölçüde bir mukavemet azalmasına yol açmamaktadır. Bu, kalsiyum-silikat yapısına ilave edilen silika aerojel partiküllerinin kimyasal olarak inaktif özellikleri nedeniyle ortaya çıkabilmektedir. Öte yandan, silika aerojellerin çimento matrisi ile olan zayıf etkileşimleri ve suyun aerojel partikül yapısında kolayca hareket edebilmesine olanak sağlayan yüksek boşluklu aerojel por yapısı, tespit edildiği gibi sınırlı düzeyde mukavemet azalmasina yol açabilmektedir [27-29]. Diğer taraftan, hidratasyon ilerledikçe, 28 günlük numunelerinin basınç dayanımlarındaki değişiklikler 7 günlük numunelerde tespit edilen eğilime oldukça benzer eğilim göstermektedir. Eşit aerojel içeriğinde, artan aktivatör dozajının numunelerin basınç mukavemeti üzerindeki pozitif etkisi belirgin bir 
şekilde görülebilmektedir. Bu sayede S3 ve S5 numunelerinde $\mathrm{S} 2$ ve $\mathrm{S} 4$ numunelerinin dayanımlarına kıyasla artan aktivatör dozajı nedeniyle kısmi bir mukavemet artışı saptanabilmiştir. Artan aktivatör miktarı, çimento matrisindeki gözenekleri hidratasyon ürünleri ile doldurur ve daha yoğun yapıdaki çimento matrisi daha yüksek basınç mukavemetleri elde edilmesine yol açar [12]. Tüm kür süreleri sonunda elde edilen sonuçlar değerlendirildiğinde, aerojel ilavesi nedeniyle basınç dayanımlarında yaşanan düşüşlerin artan kür süresi ile minimum düzeye indiğini ve 28 günlük kür süresi sonunda aerojel içeren tüm numunelerde maksimim \%2.56 düzeyinde dayanım düşüşü saptanabileceğini ortaya koymaktadır.

\section{Eğilme Dayanımı Test Sonuçları}

Şekil 3'te 2,7 ve 28 günlük numunelerde tespit edilen eğilme dayanımı sonuçları görülmektedir.

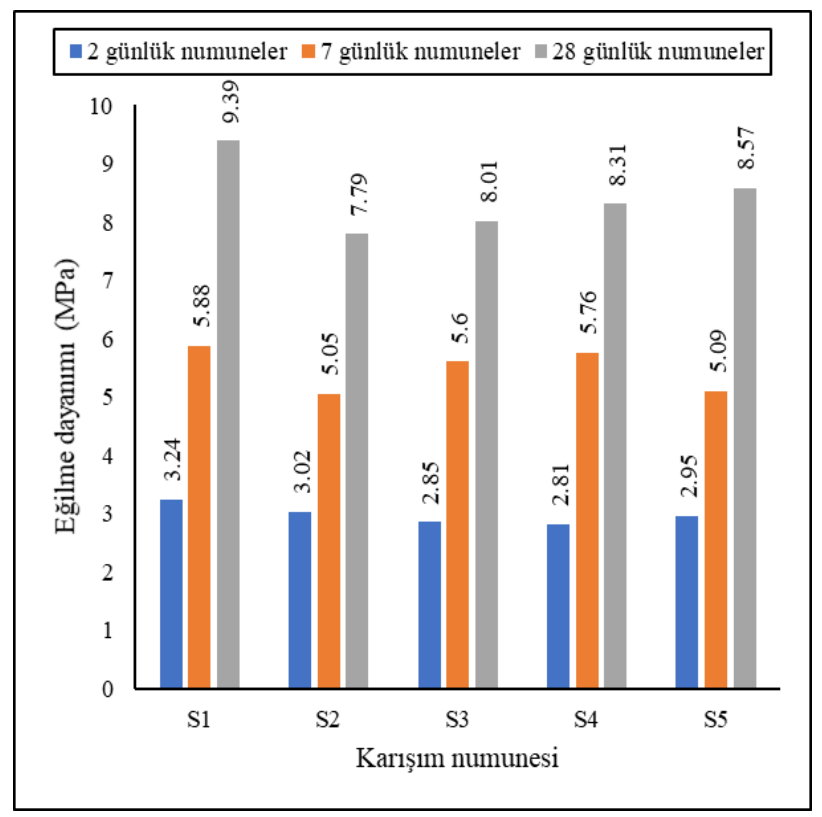

Şekil 3. 2, 7 ve 28 günlük numunelerde eğilme dayanımı test sonuçları

Şekil 3'te görüldüğü üzere tüm kür süreleri sonunda elde edilen sonuçlar, düşük katkı oranlarındaki silika aerojel ilavesinin, kontrol karışımına kıyasla tüm aerojel içeren numunelerde daha düşük eğilme dayanımlarının saptanmasına yol açtığını göstermektedir. 2 günlük kür süresi sonunda eşit aktivatör dozajında artan aerojel içeriğine bağlı olarak S1 numunesine k1yasla S3 ve S5 numunelerinin eğilme dayanımlarında düşüşler tespit edilmiştir. Basınç dayanımlarındaki eğilime benzer yönde, artan aktivatör dozajının eğilme mukavemeti gelişimi üzerindeki olumlu etkisi düşük aerojel katkısı içeren S2 ve S3 örnekleri numunelerinde tespit edilememiştir. Ayrıca, eşit aerojel katkı oranında artan aktivatör dozajının, 2 ve 7 günlük numunelerde aktivatör dozajının bir fonksiyonu olarak sürekli mukavemet gelişimi için mutlak faydalı olmadığ 1 görülmektedir. Ancak yine de 2 günlük kür süresi sonunda eşit aerojel katkı oranında artan aktivatör dozajı sayesinde S4 numunesine kiyasla S5 numunesinde \%4.98 düzeyinde eğilme dayanımı artışı saptanırken 7 günlük numunelerde S2 numunesine k1yasla S3 numunesinin dayanımındaki artış \%10.89 düzeyindedir.

Hidratasyonun ilerlemesi ile 28 günlük kür süresi sonunda, 2 ve 7 günlük numunelerden farklı olarak artan aerojel içeriğinin eğilme mukavemeti üzerindeki etkisi dikkat çekiciydi. 28 günlük eğilme dayanımı sonuçları incelendiğinde, sonuçların 28 günlük basınç dayanım sonuçları ile uyumlu son derece uyumlu olduğu görülmektedir. Daha önce tartışıldığı gibi, kontrol numunesinin eğilme mukavemeti basınç mukavemetine benzer şekilde aerojel içeren tüm numunelerden biraz daha yüksektir. Ancak, karışımlarda aktivatör ve aerojel içeriklerinin artan dozaj1, numunelerin eğilme mukavemetini de basınç dayanımında olduğu gibi olumlu yönde etkileyebilmektedir. Eşit aktivatör dozajında artan aerojel içeriği sebebiyle S4 ve S5 numunelerinin eğilme mukavemetlerinde S2 ve S3 numunelerine k1yasla sirasiyla $\% 6.67$ ve \% 6.99 düzeylerinde artışlar tespit edilmiştir. Aktivatör dozaj1 S2-S4 ve S3-S5 karışımlarında sabit tutulduğundan, eğilme mukavemetini arttıran tek parametre artan aerojel içeriğidir. Benzer şekilde eşit aerojel içeriğinde artan aktivatör dozaj1 sayesinde, S3 ve S5 numunelerinin eğilme mukavemetlerinde $\mathrm{S} 2$ ve S4 numunelerine kiyasla \% 3'e kadar kısmi artışlar saptanmıştır. Bu açıdan; eğilme dayanımı testinden elde edilen sonuçlar, basınç dayanımı deneylerinden elde edilen sonuçlarla uyum içindedir. Bu noktada, 28 günlük aerojel içeren numunelerde artan aerojel içeriğinin ve aktivatör dozajının hem basıç̧ hem de eğilme 
dayanımlarını kısmi olarak geliştirdiği net olarak söylenebilir.

\section{Cıva Porozimetresi Test Sonuçları}

Cıva porozimetresi analizi, çimento esaslı malzemelerde por yapısı özelliklerinin gelişimini anlamak için sikça tercih edilen temel ve güvenilir bir tekniktir. Numunelerin toplam porozite, ortalama por çap1 ve por boyutu dağılımları gibi por yapısı özellikleri bu yöntemle ölçülebilir [30,31]. Bu çalışmada, por yapısının değerlendirilmesi boşlukların silindirik olduğu ve temas açısının $140^{\circ}$ olduğu olağan cıva porozimetresi varsayımına göre gerçekleştirilmiştir [32,33]. Cıva porozimetresi analiz sonuçları Tablo 5'te görülmektedir.

Tablo 5. Clva porozimetresi analiz sonuçları

\begin{tabular}{|c|c|c|c|}
\hline Numune & $\begin{array}{c}\text { Toplam } \\
\text { porozite } \\
(\%)\end{array}$ & $\begin{array}{c}\text { Alansal } \\
\text { ortalama } \\
\text { por çapı } \\
(\mathbf{n m})\end{array}$ & $\begin{array}{c}\text { Hacimsel } \\
\text { ortalama } \\
\text { por } \\
\text { çapı } \\
(\mathbf{n m})\end{array}$ \\
\hline S1 & 16.74 & 4.8 & 10.4 \\
\hline S2 & 18.14 & 5 & 10.8 \\
\hline S3 & 18.04 & 4.7 & 11.1 \\
\hline S4 & 17.5 & 4.8 & 10.5 \\
\hline S5 & 17.34 & 4.6 & 10.3 \\
\hline
\end{tabular}

S1 kontrol örneğinde toplam porozite değeri \%16.74 olarak ölçülmüş olup tüm numuneler arasında minimum seviyededir. $\% 0.25$ ve $\% 0.5$ katkı oranlarındaki aerojel içerikleri nedeniyle aerojel içeren tüm karışımlarda kontrol numunesine kıyasla daha yüksek düzeyde porozite değerleri saptanmıştır. Bu durum, harç karışımlarına ilave edilen düşük miktardaki silika aerojel katkısının daha yüksek por yapısı karakteristiklerinin ölçülmesine yol açtığını ve aerojel ilavesinin harç por yapısında açık gözeneklerin oluşumunu teşvik ettiğini işaret etmektedir. Beklenildiği gibi, artan aerojel içeriği toplam porozitenin yanı sıra ortalama por çapları üzerinde de genişletici etki yaratmaktadır. S1 kontrol numunesine kiyasla aerojel içerikli numunelerinin hacimsel ortalama por çap1 ve alansal ortalama por çapı değerlerinde sırasıyla \% 6.73 ve \%4.16'a varan kısmi artışlar ölçülmüştür. Bununla birlikte, eşit aerojel katkı oranında aktivatör dozajındaki \% 0.1 'den $\% 0.2$ 'ye olan artış, S2 ve S4 numunelerine kıyasla S3 ve S5 numunelerinin alansal ortalama por çap1 değerlerinde sirasiyla $\% 6$ ve $\% 4.16$ düzeylerinde düşüşlere neden olmaktadır. Buradaki en olas1 mekanizma, artan aktivatör dozajı ile hızlanan puzolanik reaksiyonun olumlu etkisine atfedilebilir. Daha önce tartışıldığ 1 gibi, artan aktivatör dozajı hidratasyon ürünleri ile yeterince dolmamış olan gözenekleri doldurmakta ve gözenek yapısı karakteristiklerinde daha düşük değerlere yol açabilmektedir [12].

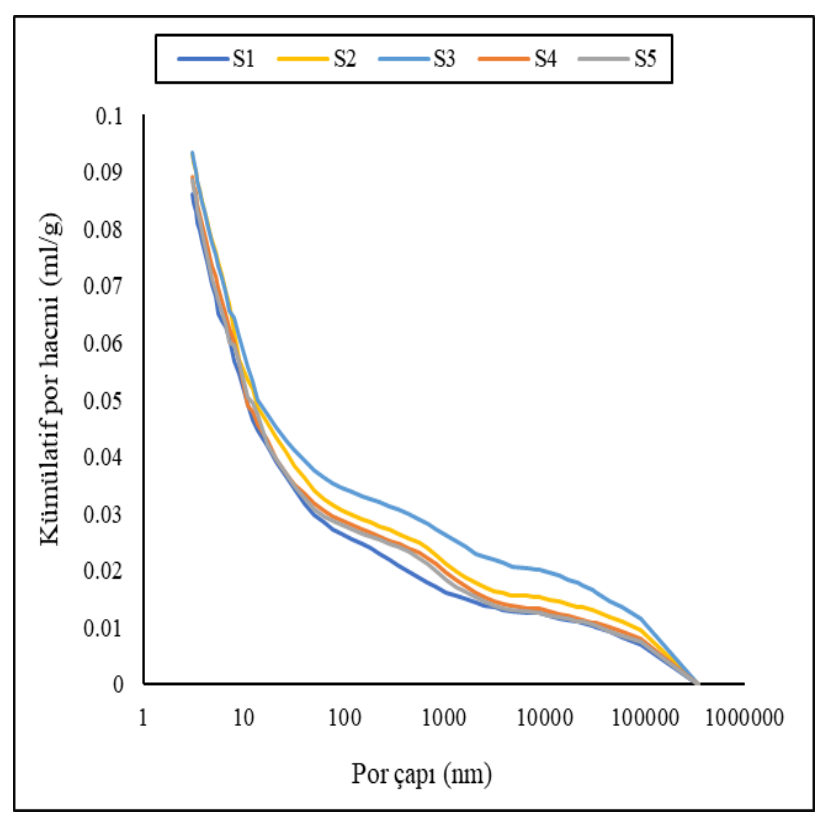

Şekil 4. Hibrit harç numunelerinde kümülatif por hacmi-por çapı ilişkisi

Şekil 4, 28 günlük kür süresinin tamamlanması ile tüm numuneler için kümülatif por hacmi - por çapı ilişkisini ifade eden eğrilerin gelişimini göstermektedir. Şekilde görüldüğü gibi, aerojel katkısı içermeyen kontrol numunesi aerojel katkılı numunelere kıyasla ölçüm işleminin gerçekleştirildiği 3 ila $350,000 \mathrm{~nm}$ arasındaki tüm gözenek boyutlarında daha düşük kümülatif por hacmi sergilemiştir. Bu nedenle, numunelerin por yapısındaki toplam por hacminin porozite sonuçlarına da yansıdığı gibi düşük katkı oranlarındaki silika aerojel katkısı vasitasıyla kolayca arttırılabileceği görülmektedir. Kontrol numunesi için tespit edilen davranış ile uyumlu 
olarak poroziteleri $\approx \% 18$ olan S2-S3 numuneleri, poroziteleri $\approx \% 17$ olan S4-S5 numunelerine kıyasla 3 ve $350,000 \mathrm{~nm}$ arasındaki por çap1 aralığı boyunca daha yüksek por hacmi sergilemiştir. $\mathrm{Bu}$ nedenle, aerojel içeren numunelerin por hacmindeki artışın, numunelerin toplam porozite değerleri ile uyumlu olduğu net olarak gözükmektedir. Öte yandan, toplam porozite değerindeki artış ile uyumlu olarak S4 örneğinin kümülatif por hacmi - por çap1 eğrisinin tüm por çap1 aralıkları boyunca S5 örneğine kıyasla yukarıda seyretmesi oldukça makuldür. Bununla birlikte, beklenenin aksine, S3 numunesinin kümülatif por hacmi eğrisi, daha düşük porozite değerine rağmen 20 ve 350,000 $\mathrm{nm}$ arasındaki por boyutlarında S2 örneğine kıyasla daha üst seviyede seyretmektedir. Marjinal davranışa yol açan esas faktör, ilgili numunelerin hacimsel ortalama por çap1 değerlerinden görülebilmektedir. Eşit aerojel içeriğinde artan aktivatör dozajı sebebiyle toplam porozite ve alansal ortalama por çap1 karakteristiklerindeki düşüşlere rağmen, hacimsel ortalama por çapında ölçülen artış, por yapısının gelişimi üzerinden baskın etki yaratabilmektedir.

Çimento esaslı malzemelerin por yapılarının değerlendirilmesinde pek çok por yapısı sınıflandırması önerisi mevcut olmasına rağmen boşluklar genel olarak jel boşlukları $(<10 \mathrm{~nm})$, kapiler boşluklar $(10-10,000 \mathrm{~nm})$ ve makro boşluklar $(>10,000 \mathrm{~nm})$ olmak üzere üç ana kategoride değerlendirilebilmektedir [34]. Farklı aerojel katkı oranlarındaki harç numunelerinin por yapısı gelişimleri yukarıda belirtilen sınıflandırma esasına göre Şekil 5'te gösterilmektedir.

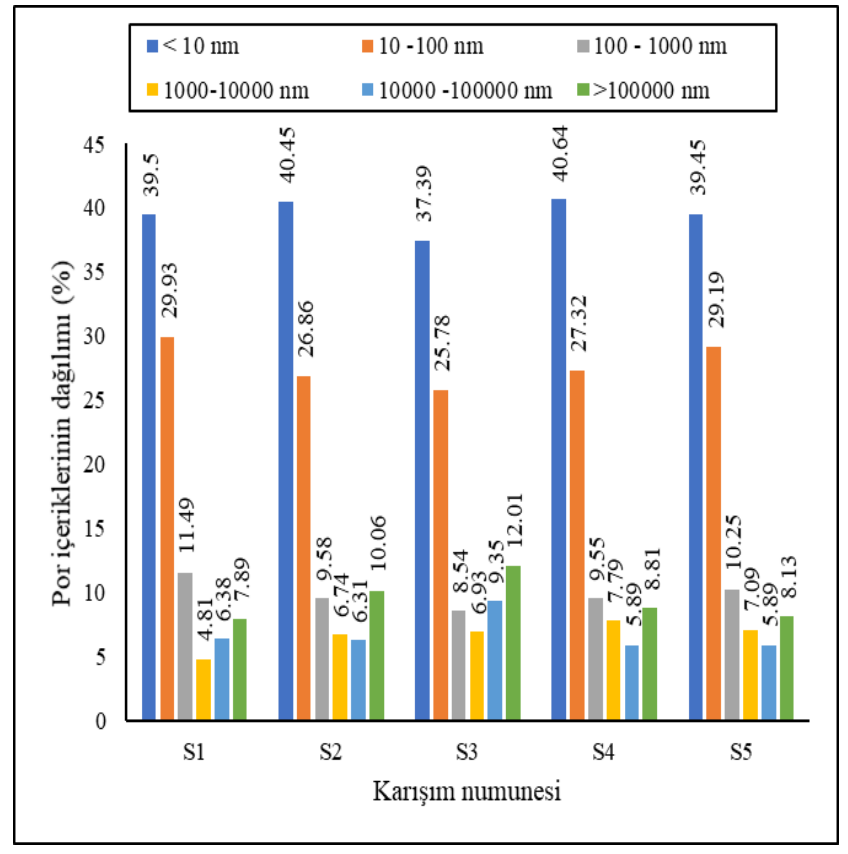

Şekil 5. Harç por yapısında por içeriklerinin dağılımı (\%)

Şekil 5'te görüldüğü gibi, hibrit karışımlarda kullanılan silis dumanının gözenek doldurma etkisine bağlı olarak, $10 \mathrm{~nm}$ ve altındaki boyutlardaki gözeneklerin hacmi, değişen aerojel içeriği ve aktivatör dozajına rağmen toplam por hacminin \%37.39 ile \%40.64'ü arasında değişmektedir. Bu durum, alkali-aktive edilmiş hibrit harç karışımlarında bağlayıcı malzeme içeriğinde silis dumanının kullanılmasının geleneksel çimento karışımlarına kıyasla daha yüksek jel boşluk oluşumuna yol açtığını işaret etmektedir. Öte yandan, 100,000 nm' den büyük çaplı boşluk oluşumlarındaki değişim incelendiğinde por yapısı gelişimi aerojel ilavesinden güçlü bir şekilde etkilenmiştir. $\mathrm{Bu}$ nedenle, kontrol numunesinde ölçülen 100,000 $\mathrm{nm}$ 'den büyük por çaplarının oluşturduğu makro gözenek oluşumu \%7.89 düzeyinde iken S2, S3, S4 ve S5 örneklerinde daha yüksek bir makro gözenek içeriği (sırasıyla \%10.06, \%12.01, $\% 8.81$ ve $\% 8.13$ düzeylerinde) tespit edilmiştir. Beklendiği gibi, \%0.25 aerojel ilavesi için S2-S3 numunelerinde $\% 0.5$ aerojel içerikli numunelere kıyasla numunelerin daha yüksek toplam porozite değerleri ile uyumlu olarak daha yüksek makro gözenek oluşumları tespit edilmiştir. Bu nedenle, makro gözenek oluşumlarının numunelerin toplam porozite değerleri üzerinde belirleyici faktör olduğu söylenebilmektedir. Ayrıca, partikül boyutu 8-10 $\mathrm{nm}$ arasında olan silika 
aerojel partikülleri, karışımlara ilave edildiklerinde kendi jel boşluk düzeyindeki por çaplarına rağmen harç por yapısında makro gözenek oluşumunu tetikleyebilmektedir.
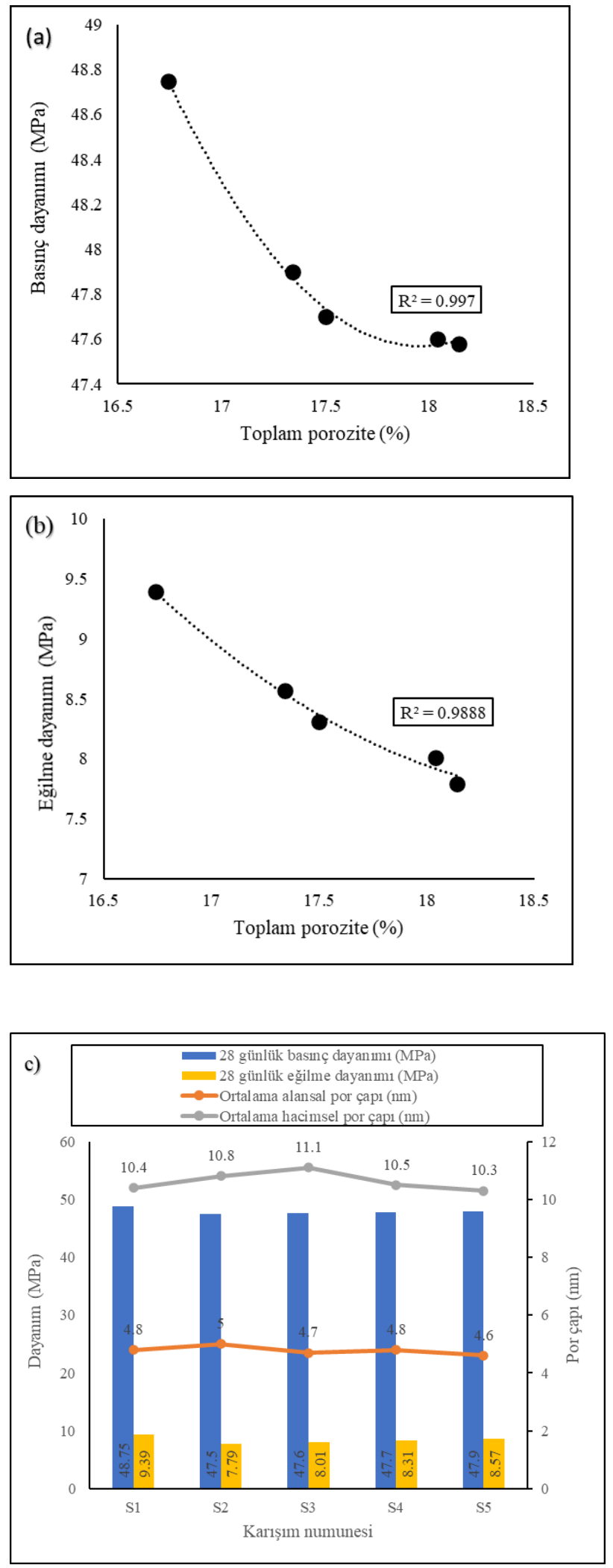

Şekil 6. Dayanım de ğerleri ile por yapısı parametreleri arasındaki ilişkiler
Şekil 6'da harç numunelerinde tespit edilen mekanik özellikler ile por yapısı karakteristikleri arasındaki ilişkiler görülmektedir. Mevcut ilișkiler, karışımlara düşük katkı oranlarında ilave edilen silika aerojel katkısının mekanik özellikler üzerindeki etkisinin anlaşılmasına katkı sunabilecek düzeydedir. Elde edilen sonuçlar, por yapısı karakteristiklerinin, harç numunelerinin basınç ve eğilme mukavemetlerini önemli ölçüde etkileyebildiğini işaret etmektedir. Harç numunelerinin porozite değerlerindeki artış, alkali-aktivasyonu ile oluşturulan $\mathrm{C}-\mathrm{S}-\mathrm{H}$ jeli ile yeterince doldurulamayan büyük gözenekleri işaret etmektedir. Ek olarak, daha yüksek porozite değerlerinde saptanan daha yüksek ortalama çap değerlerinin varlığı boşluklu yapıyı doğrulamaktadır. Bu nedenle, porozite ve alansal ortalama por çapı değerleri arttı̆̆ında, harçların hem basınç hem de eğilme mukavemetleri azalmaktadır. Eşit aerojel katkısında aktivatörün artan dozajı, daha önce tartışıldığı gibi, porozite ve ortalama por çap1 değerlerinde düşüşlerle sonuçlanmıştır. Cıva porozimetresi sonuçlarına göre artan aktivatör dozu ilave C-S-H jeli oluşumuna katkıda bulunabilir. Gözeneklerde ilave C-S-H jelinin bulunması, daha az boşluklu ve daha yoğun boşluk yapısı elde edilmesine yol açar ve daha az boşluklu yapı numunelerin dayanım değerlerini olumlu yönde etkiler. Deneysel sonuçlar, harç karışımlarına ilave edilen düşük katkı oranlarındaki silika aerojel katkısı ile harç numunelerinin toplam porozite değerlerinde maksimum \%1.4'lük bir artışın gözlenebileceğini ve $\operatorname{artan}$ porozite sebebiyle de basınç mukavemetinde maksimum \%2.56'l1k bir azalmanın oluşabileceğini ortaya koymaktadır. Bununla birlikte, basınç dayanımındaki sınırlı düşüşe karşın eğilme mukavemetinde $\% 17$ ' ye kadar saptanan kayıplar dikkat çekicidir. Tespit edilen mukavemet düşüşü esasen alansal ortalama por çap1 değerinde ölçülen \%4.16'a kadar olan artışla ilişkiliydi. Bu noktada, aerojel katkılı numunelerin eğilme performanslarının, basınç etkisi altındaki performanslarına kıyasla por yapısı karakteristiklerindeki bir artışa daha duyarlı olduğu sonucuna varılabilir. İlaveten, mekanik özellikler ile por yapısı karakteristikleri arasında saptanan ilişkiler alkali-aktive edilmiş hibrit silis dumanı harçlarında 28 günlük basınç ve eğilme dayanımlarının numunelerin toplam 
porozite değerleri aracılığ ve 0.98 korelasyon katsayısı ile tahmin edilebileceğini ortaya koymaktadır. Tespit edilen yüksek korelasyon, hibrit silis dumanı harçlarının tasarımı için por yapısı karakteristiklerinin esas alınmasını teşvik edici ölçektedir.

\section{Termal İletkenlik Katsayısı Sonuçları}

Tablo 6'da hibrit harç numunelerinin termal iletkenlik katsayısı ölçüm sonuçları görülmektedir. Harç örneklerinde saptanan termal iletkenlik katsayıları 1.31 ile 1.83 $\mathrm{W} /(\mathrm{m} . \mathrm{K})$ aralığında değişmektedir.

\section{Tablo 6. Termal iletkenlik katsayısı ölçüm sonuçları}

\begin{tabular}{|c|c|}
\hline $\begin{array}{c}\text { Termal iletkenlik katsayısı } \\
\text { W/(m.K) }\end{array}$ \\
\hline S1 & 1.83 \\
\hline S2 & 1.31 \\
\hline S3 & 1.34 \\
\hline S4 & 1.39 \\
\hline S5 & 1.43 \\
\hline
\end{tabular}

Tablo 6'da görüldüğü gibi, termal iletkenlik katsayısı ölçüm sonuçlarına dayanarak karışımlara ilave edilen düşük miktardaki silika aerojel katkısı sayesinde hibrit harç numunelerinin termal yalıtkanlık özelliklerinin önemli ölçüde gelişebileceği görülmektedir. Kontrol numunesinde termal iletkenlik katsayısı $1.83 \mathrm{~W} /(\mathrm{m} . \mathrm{K})$ olarak saptanmıştır. Harç karışımlarına ilave edilen $\% 0.25$ oranındaki aerojel katkısı sayesinde S2 ve S3 harç numunelerinin termal iletkenlik katsayıları kontrol örneğinden sirasiyla \%28.41 ve \%26.77 düzeylerinde daha düşüktür. Termal iletkenlik katsayılarındaki düşüşler esas olarak aerojel partiküllerinin üstün ısıl yalıtım özelliklerinden kaynaklanmaktadır [30,31]. Harç karışımlarına \% 0.5 katk1 oranında aerojel dahil edilmesi durumunda da numunelerin yalitkanlık performanslarında benzer eğilimler gözlenmiştir. Kontrol numunesine kiyasla S4 ve S5 numunelerinin isil iletkenliklerinde sirasiyla $\% 24.04$ ve \%21.85 düzeylerinde düşüşler olduğu saptanmıştır. Öte yandan, hem $\% 0.25$ hem de $\%$
0.5 aerojel katkı oranlarında artan aktivatör dozajı ile termal iletkenlik katsayılarında kısmi düzeyde artışlar ölçülmüştür. Daha önce tartışıldığı gibi, aktivatör dozajının arttırılması, daha az gözenekli yapıya sahip daha yoğun çimento matrisine yol açabilmektedir. Bu nedenle, 1sı transferi için katı parçacıklar arasında kolaylaşan etkileşim, yukarıda gösterilen iletkenlik katsayılarındaki artışı açıklayabilir. Bununla birlikte elde edilen sonuçlar harç karışımlarında düşük miktardaki aerojel ilavesinde dahi numunelerin 1s1 yalıtım özelliklerinin \%28 düzeyinde gelişebildiğini işaret etmektedir.

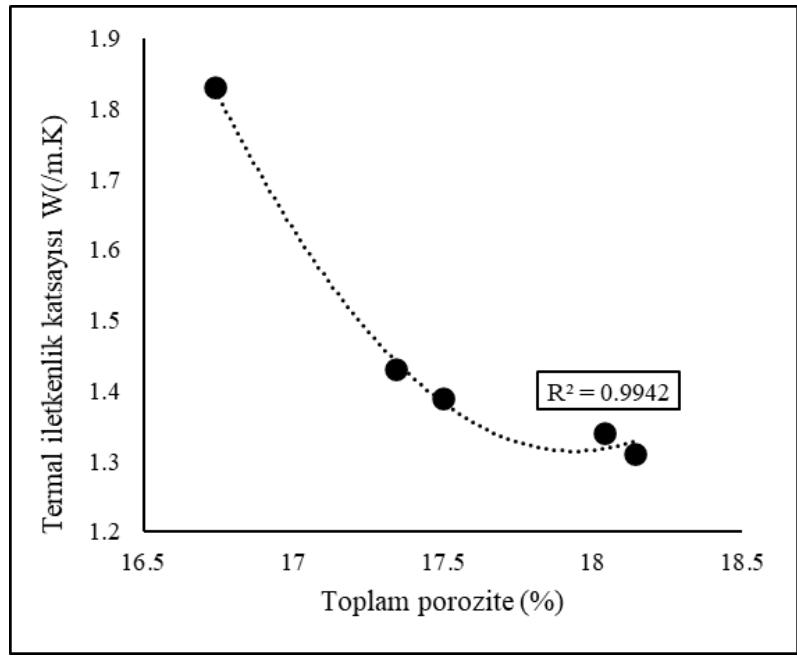

Şekil 7. Toplam porozite - termal iletkenlik katsayısı ilişkisi

Şekil 7, harç numunelerinde ölçülen toplam porozite-termal iletkenlik katsayısı değerleri arasındaki ilişkiyi göstermektedir. Silika aerojel partiküllerinin üstün 1sı yalıtım özelliklerine ek olarak, aerojel katkılı çimento esaslı malzemelerde por yapısının gelişimi, numunelerde daha düşük iletkenlik katsayılarının ölçülmesine katkıda bulunabilmektedir. Sonuçlardan, bağlayıcı malzeme içeriğine az miktarda silika aerojel tozu ilave edildiğinde 1 sıl muhafaza performansında önemli bir artış olduğu görülebilir. Hibrit silis dumanı harçlarında yüksek düzeydeki jel oluşumundan kaynaklı kararlı por yapisı nedeniyle numunelerin toplam porozite ve termal iletkenlik katsayıları arasında $\mathrm{R}^{2}=0.99$ değeri ile anlaşılabileceği üzere güçlü bir etkileşim bulunmaktadır. Kontrol numunesine kıyasla, S2 numunesinin toplam porozite değerinde maksimum \%1.4'lük bir artış numunenin termal iletkenlik katsayısında 
\%28.41'lik düşüşe olanak sağlayabilmektedir. Gözenek yapısı ayrıca diğer numunelerin iletkenlik katsayıları üzerinde de bağlayıcı olmuştur. Eşit aktivatör dozajında aerojel içeriğinde $\% 0.25$ 'ten $\% 0.5$ 'e olan artış $\mathrm{S} 2$ ve $\mathrm{S} 3$ numunelerine k1yasla S4 ve S5 numunelerinin toplam porozite değerlerinde $0.64 \%$ ve $0.7 \%$ düzeylerinde düşüşlere neden olmaktadır. $\mathrm{Bu}$ nedenle, daha yüksek aerojel içeriğinde por yapısı özelliklerinde tespit edilen düşüşler oluşan daha yoğun matrisi işaret etmekte ve bu durum artan partikül etkileşimi ile daha iyi isı iletkenliğine yol açmaktadır.
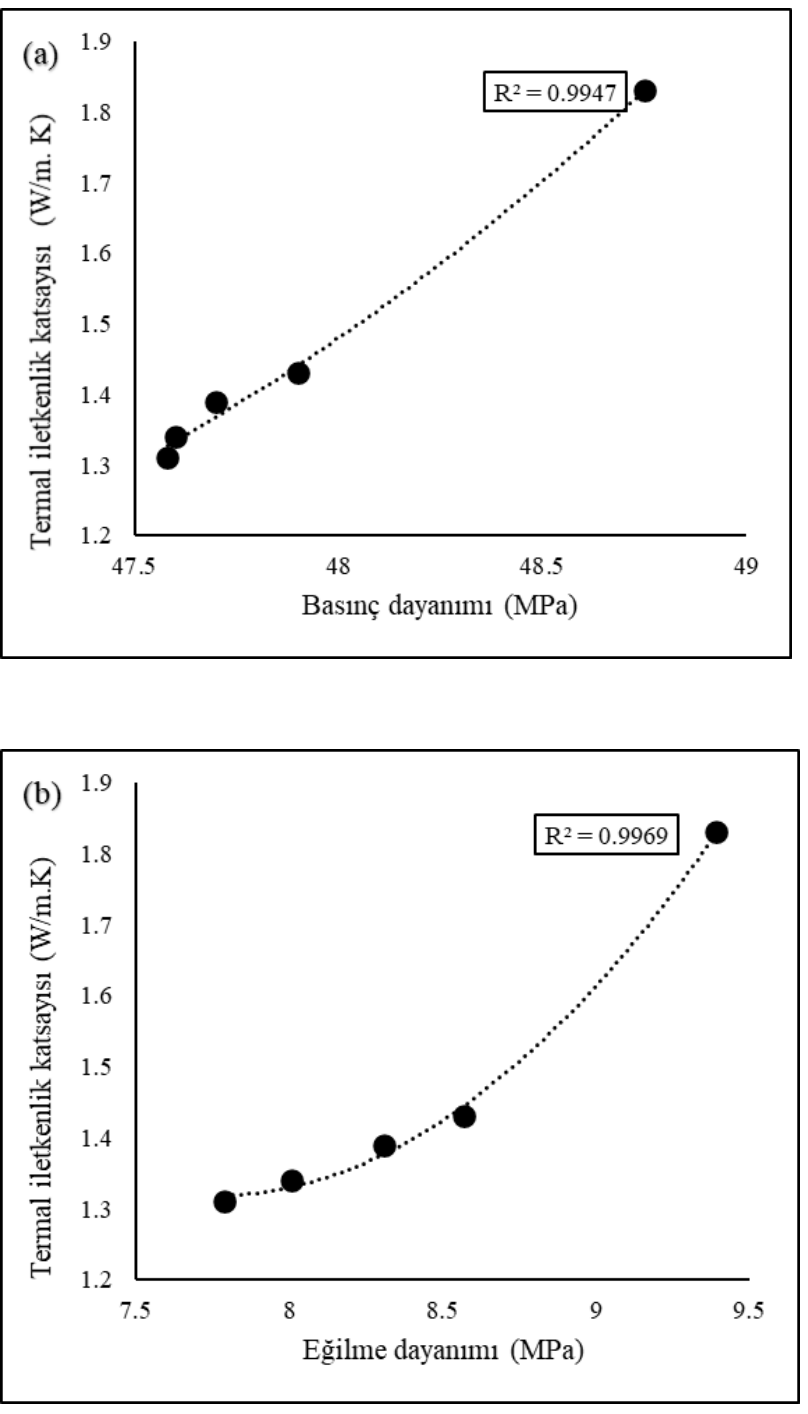

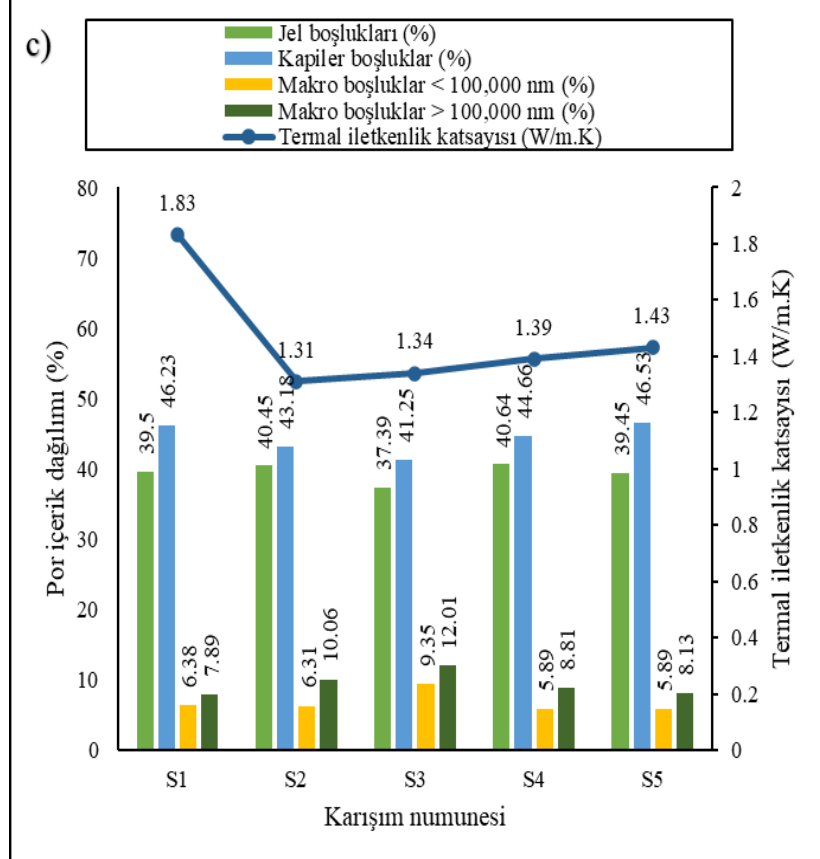

Şekil 8. Harç numunelerinin mekanik, por yapısı özellikleri ve termal iletkenlik katsayılar arasındaki ilişkiler

Şekil 8, harç numunelerinde tespit edilen mekanik özellikler, por yapısı özellikleri ve termal iletkenlik katsayısı arasındaki ilişkiyi göstermektedir. Beklendiği gibi, por yapısı karakteristikleri ile olan uyum göz önüne alındığında, dayanım sonuçları termal iletkenlik test sonuçları ile uyum içerisindedir. Numunelerde eşzamanlı olarak saptanan iletkenlik ve mukavemet düşüşleri, aerojel içeriğinde harç gözenek yapısındaki meydana gelen ilave gözenek oluşumuna bağlanabilir. Öte yandan, 100.000 ile $350.000 \mathrm{~nm}$ arasındaki por çapı aralıklarında saptanan por içerikleri, \%0.5'lik aerojel katkılı numunelere kıyasla daha düşük aerojel içeriğine rağmen $\% 0.25$ aerojel katkılı numunelerde saptanan daha düşük termal iletkenlik katsayısı değerlerinin sebeplerini ortaya koymaktadir. S2 ve S3 numunelerinde 100.000 ve $350.000 \mathrm{~nm}$ arasındaki por içeriği, toplam por içeriğinin $\% 10.06$ ve \%12.01's1 kadardır. Bununla birlikte, \% 0.5 aerojel katkıs1 durumunda, aynı çap aralığındaki por içeriği S4 ve S5 numunelerinde sirasiyla $\% 8.81$ ve $\% 8.13$ düzeylerinde saptanmıştır. Ayrıca, söz konusu gözenek boyutlarındaki por içeriği kontrol numunesinde minimum seviyededir (\%7.89). Deneysel sonuçlar, numunelerdeki makro gözenek oluşumunun numunelerin termal 
iletkenlik davranışı üzerindeki etkinliğini işaret etmektedir. Ayrıca, eşit aerojel katkı oranında artan aktivatör dozaj1, numunelerin toplam porozite ve alansal ortalama por çapı gibi por yapısı özelliklerinde dramatik düşüşlere neden olmaktadır, bu durum da artan aktivatör dozajının numunelerin termal iletkenlik katsayısında yol açtığ 1 artış1 desteklemektedir.

\section{SEM Analizi}

Taramalı elektron mikroskobu aracılı̆̆ numunelerinin mikro yap1 özelliklerini tespit etmek amaciyla SEM analizi gerçekleştirilmiştir. Mekanik testlerden geriye kalan parçaların kırılma yüzeyinden hassas olarak alınan örnekler SEM analizine tabi tutulmuş ve elde edilen mikro yap1 görüntülemeleri Şekil 9'da sunulmuştur.
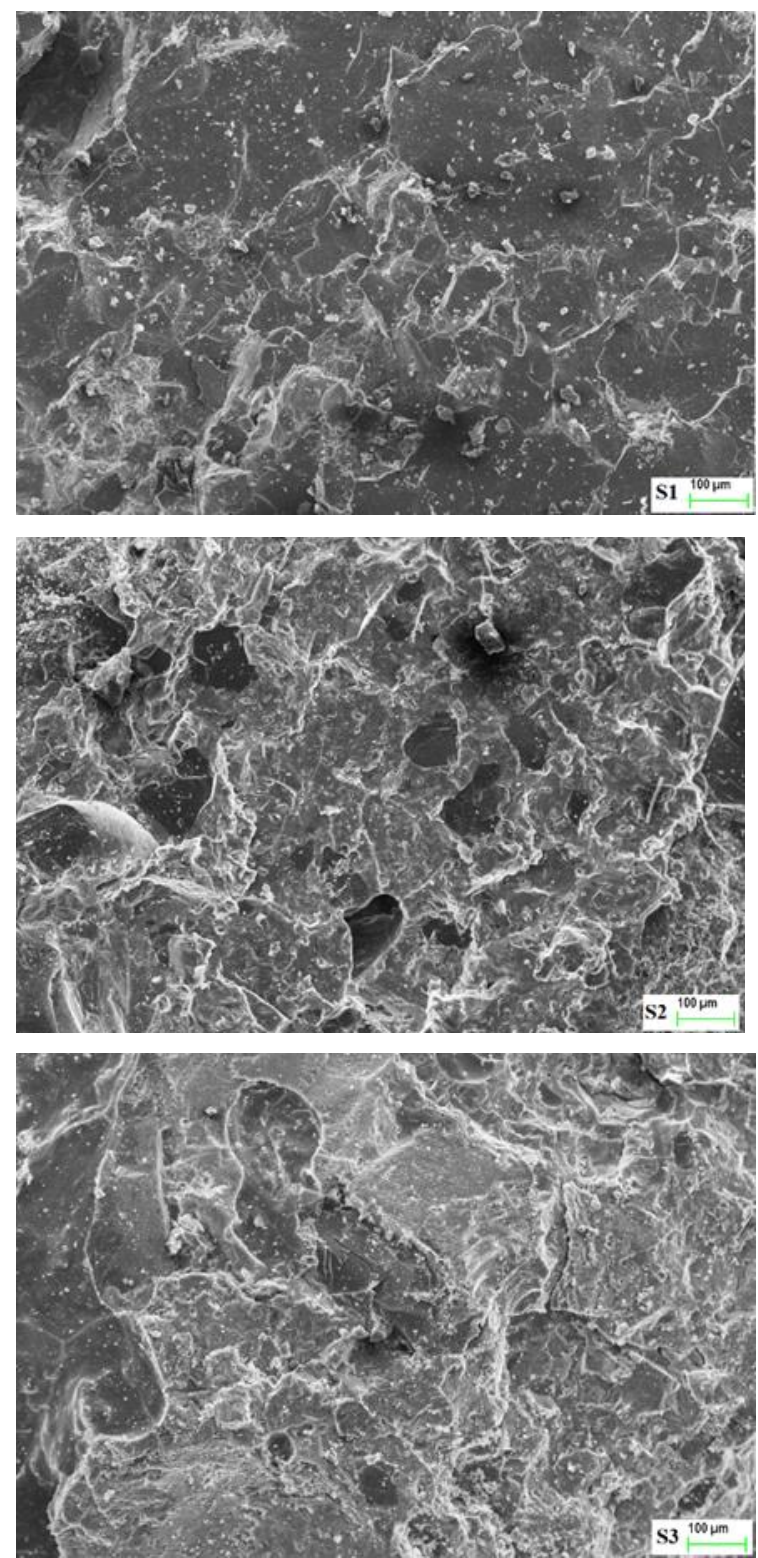
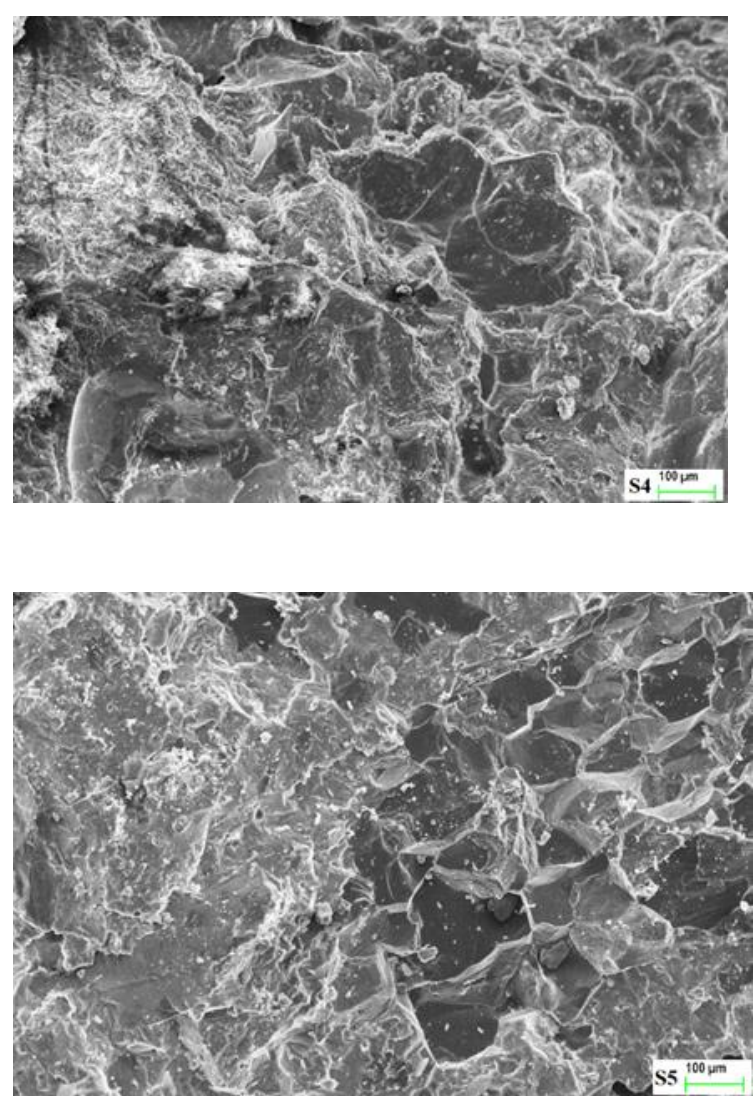

Şekil 9. 200x büyütmede harç örneklerinin SEM mikrograflarl

SEM mikro yap1 görüntülemelerinde ayırt edilebileceği üzere düzgün olarak dağılmış aerojel partiküllerini içeren faz mikro yap1 görüntülemelerinde açık gri renkte ve aerojel içermeyen homojen çimento matrisi ise koyu gri renkte belirginleşerek ortaya çıkmaktadır. Ayrıca, aerojel içerik oranında $\% 0.25$ 'ten $\% 0.5$ 'e olan artış, S4 ve S5 numunelerinde S2 ve S3 numunelerine kıyasla daha belirgin ve daha açık gri tonlarda görsel olarak artan aerojel içeriğinin gözlemlenmesine olanak sağlamaktadır. Silika aerojel partiküllerinin kalsiyum-silikat yapısındaki inert özelliklerinin bir sonucu olarak, yüzeyde aerojel toz parçacıklarının izleri belirgindir. Bu özellik, iyi hidrate olmuş çimento matrisinde aerojel partiküllerinin belirgin şekilde ayırt edilmesine olanak sağlar. S1 numunesinin SEM görüntülemesinde, diğer örneklerle karşılaştırıldığında, çimento matrisi en düşük seviyede ölçülen toplam porozite değeri ile uyumlu olarak oldukça yoğun formda görünmektedir. Düzgün yüzey dokusuna sahip olan yoğun matris yapıs1, 1sı transferi için katı parçacıklar arasındaki etkileşimi kolaylaştırmakta ve bu nedenle bu örnekte en 
yüksek termal iletkenlik katsayısı kontrol numunesinde saptanmaktadır. Diğer yandan, aerojel katk11 numunelerin mikro yap1 görüntülemeleri, aerojel partiküllerinin çimento matrisine dahil edilmesinin aerojel partikülleri ile çimento matrisinin etkileşim bölgelerinde gözenekli bir etkileşim mekanizmasına yol açtı̆̆ını göstermektedir. Bu mekanizma sadece 1S1 transfer seviyesini güçleştirmekle kalmaz, aynı zamanda 1sı transferini de büyük ölçüde engeller. Ayrıca, aerojel parçacıklarının hidrofobik yapısı, partiküllerin matris ile olan birleşim bölgelerinde su emilimini azaltarak 1s1 yalıtım hedefine katkı sunmaktadır [27].

\section{Sonuçlar}

$\mathrm{Bu}$ çalışmada, çimento katkı maddesi olarak düşük içerikteki silika aerojel ilavesinin hibrit harç numunelerinin mekanik, termal iletkenlik, gözenek yapısı özellikleri ve mikro yap1 morfolojisi üzerindeki etkisi ayrıntılı olarak araştırılmıştır. Deneysel çalışmanın sonuçlarına dayanarak, aşağıdaki çıkarımlar yapılabilir:

- Harç karışımlarına çimento ağırlığınca düşük katkı oranlarında ilave edilen silika aerojel katkısı numunelerin termal yalıtkanlık performansı üzerinde oldukça etkilidir.

- $\% 0.25$ aerojel katk1lı numunelerde sadece $\% 2.56$ düzeyindeki basınç dayanımı düşüşüne karşın termal yalıtkanlık performans1 \%28 seviyesine kadar gelişebilmektedir.

- Geleneksel çimento harçlarından farklı olarak alkali-aktive edilmiş hibrit silis dumanı harçlarında jel gözenek oluşumu toplam por hacminin yaklaşık \%40'1 düzeyindedir.

- Jel gözenek oluşumunun yüksek seviyesine bağlı olarak, kapiler gözeneklerin oluşumu sınırlanmakta ve böylece karışımlara ilave edilen silika aerojel katkısının harç numunelerinin basınç mukavemeti üzerindeki olumsuz etkisi sinırlanabilmektedir.

- Harç karışımlarına ilave edilen düşük katkı oranındaki silika aerojel içeriğinin numunelerin termal yalıtkanlık performansı üzerindeki pozitif etkisi numunelerin por yapıs1 özellikleri gelişimi üzerindeki baskın etkisi nedeniyle oluşmaktadır. $\mathrm{Bu}$ sebeple numunelerin porozite değerleri ile termal iletkenlikleri arasında yüksek korelasyon saptanabilmektedir $\left(\mathrm{R}^{2}>0.99\right)$.

- Alkali-aktive edilmiş hibrit silis dumanı harçlarında numunelerin basınç ve eğilme dayanımları ile termal iletkenlik katsayısı arasındaki ilişki de oldukça güçlüdür $\left(\mathrm{R}^{2}>0.99\right)$.

- Harç numunelerinin termal yalıtkanlık performans1 artan por hacmi ile orantilı olup toplam porozite ve alansal ortalama por çapı değerlerinde eş zamanlı artış olmas1 durumunda, 1s1 iletkenlik katsayısındaki azalma maksimum düzeyde seyretmektedir.

- Harç karıșımlarına ilave edilen silika aerojel katkısının numunelerin mekanik performansı üzerindeki olumsuz etkisi basınç dayanımlarına kıyasla daha çok eğilme performansı üzerinedir. Yine de eğilme dayanımlarında tespit edilen maksimum \%17 düzeyindeki düşüşe karşın saptanan minimum $7.79 \mathrm{MPa}$ 'lik eğilme dayanımı değeri mekanik performans açısından oldukça yeterli seviyededir.

- Aerojel partiküllerinin çimento matrisine dahil edilmesi, çimento matrisinde aerojel partiküllerinin çevresinde gözenekli ve zayıf bir katı-katı etkileşim mekanizmasına yol açmaktadır. $\mathrm{Bu}$ mekanizma mekanik dayanımlarda kısmi düzeyde düşüşlere sebep olsa da 1s1 transfer oranının düşürülmesinde oldukça önemli bir rol oynamaktadır.

Özetle bu çalışma, aerojel partiküllerinin harç karıșımlarında yüksek katkı oranlarında yer almasını öngören aerojel-kum yer değişimi esaslı tasarım tercihlerine alternatif olarak, harç karışımlarına çimento katkı maddesi olarak aerojel ilavesinin numunelerin mekanik, por yapısı, termal iletkenlik ve mikro yapı özellikleri üzerindeki etkisini detaylı olarak göstermiştir. Deneysel çalışmadan elde edilen sonuçlar, 
çimento katkı maddesi olarak silika aerojel ilavesi durumunda, harç numunelerinin mekanik özelliklerinde sınırlı düzeydeki düşüşlere karşın numunelerin termal yalıtkanlığında dikkate değer bir artışın mümkün olabileceğini ortaya koymaktadır. Karışımın homojenliği ve aerojel partiküllerinin çimento matrisinde iyi dağılımı, gelişmiş 1sı yalıtımı ile mekanik özelliklerin saptanmasında önemli bir faktör gibi görünmektedir. Son olarak, bu çalışma alkaliaktive edilmiş hibrit silika aerojel içerikli harçların tasarımı hakkında yeni bir perspektif açarak sürdürülebilirlik politikaları ile uyumlu harç tasarımı gelişimine katkı sunmaktadır.

\section{Kaynaklar}

[1]. Arbi, K., Palomo, A., Fernández-Jiménez, A. (2013). Alkali-activated blends of calcium aluminate cement and slag/diatomite, Ceramics International, 39, 9237-9245.

[2]. Cheah, C. B., Tan, L. E., Ramli, M. (2019). The engineering properties and microstructure of sodium carbonate activated fly ash/ slag blended mortars with silica fume, Composites Part B,160, 558-572.

[3]. Madani, H., Norouzifar, M. N., Rostami, J. (2018). The synergistic effect of pumice and silica fume on the durability and mechanical characteristics of ecofriendly concrete, Construction and Building Materials, 174, 356-368.

[4]. Imbabi, M. S., Carrigan, C., McKenna, S. (2012). Trends and developments in green cement and concrete technology, International Journal of Sustainable Built Environment,1, 194-216.

[5]. Liu, Y., Shi, C., Zhang, Z., Li, N. (2019). An overview on the reuse of waste glasses in alkaliactivated materials, Resources, Conservation and Recycling, 144, 297-309.

[6]. Schröfl, C., Gruber, M., Plank, J. (2012). Preferential adsorption of polycarboxylate superplasticizers on cement and silica fume in ultrahigh performance concrete (UHPC), Cement and Concrete Research, 42, 1401-1408.

[7]. Gesoglu, M, Guneyisi, E., Asaad, D.S., Muhyaddin, G.F. (2016). Properties of low binder ultra-high performance cementitious composites: Comparison of nanosilica and microsilica, Construction and Building Materials, 102,706-713.

[8]. Zelic, J., Rusic, D., Veza, D. , Krstulovic, R. (2000). The role of silica fume in the kinetics and mechanisms during the early stage of cement hydration, Cement and Concrete Research, 30, 6551662.

[9]. Rossen, J.E., Lothenbach, B., Scrivener, K. L. (2015). Composition of C-S-H in pastes with increasing levels of silica fume addition, Cement and Concrete Research, 75, 14-22.

[10]. Ng, S., Jelle, B. P., Stæhli, T. (2016). Calcined clays as binder for thermal insulating and structural aerogel incorporated mortar, Cement and Concrete Composites, 72, 213-221.

[11]. Luo, Y., Jiang, Y. ,Feng, J. (2019). Synthesis of white cement bonded porous fumed silica-based composite for thermal insulation with low thermal conductivity via a facile cast-in-place approach, Construction and Building Materials, 206, 620-629.

[12]. Bostanc1, L. , Sola, O.C. (2018). Mechanical Properties and Thermal Conductivity of AerogelIncorporated Alkali-Activated Slag Mortars, Advances in Civil Engineering, 2018, 1-9.

[13]. Szodrai, F., Lakatos, Á. , Kalmár, F. (2016). Analysis of the change of the specific heat loss coefficient of buildings resulted by the variation of the geometry and the moisture load, Energy, 115, $820-829$.

[14]. Lakatos, Á. (2019). Stability investigations of the thermal insulating performance of aerogel blanket, Energy and Buildings, 185, 103-111.

[15]. Huang, Y. , Niu, J.-1. (2015). Energy and visual performance of the silica aerogel glazing system in commercial buildings of Hong Kong, Construction and Building Materials, 94, 57-72.

[16]. Kim, S., Seo, J., Cha, J. , Kim, S. (2013). Chemical retreating for gel-typed aerogel and insulation performance of cement containing aerogel, Construction and Building Materials, 40, 501-505.

[17]. Cuce, E., Cuce, P. M., Wood, C. J., Riffat, S.B. (2014). Toward aerogel based thermal superinsulation in buildings: A comprehensive review, Renewable and Sustainable Energy Reviews, 34, 273-299.

[18]. Dorcheh, A.S., Abbasi, M.H. (2008). Silica aerogel; synthesis, properties and characterization, Journal of Materials Processing Technology, 199,10-26.

[19]. Wang, L., Liu, P., Jing, Q., Liu, Y., Wang, W., Zhang, Y., Li, Z. (2018). Strength properties and thermal conductivity of concrete with the addition of expanded perlite filled with aerogel, Construction and Building Materials, 188, 747-757.

[20]. Ng, S., Jelle, B. P., Sandberg, L. I. C., Gao, T., Wallevik, O. H. (2015). Experimental investigations 
of aerogel-incorporated ultra-high-performance concrete, Construction and Building Materials, 77, 307-316.

[21]. Liu, Z. H., Ding, Y.D., Wang, F., Deng, Z.P. (2016). Thermal insulation material based on $\mathrm{SiO} 2$ aerogel, Construction and Building Materials, 122, 548-555.

[22]. Al Zaidi, A. K. A., Demirel, B. , Atis, C.D. (2019). Effect of different storage methods on thermal and mechanicalproperties of mortar containing aerogel, fly ash and nano-silica, Construction and Building Materials, 199, 501-507.

[23]. TSI, TS EN 197-1. Cement-Part 1: Compositions and conformity criteria for common cements. Ankara, Turkey: Turkish Standard Institute; 2002.

[24]. TSE, TS EN 196-1. Methods of testing cement-Part 1: Determination of strength. Ankara, Turkey: Turkish Standard Institute; 2009 [in Turkish].

[25]. TS EN 1015-11 Methods of Test for Mortar for Masonry - Part 11: Determination of Flexural and Compressive Strength of Hardened Mortar.

[26]. Bilim, C. , Atis, C.D. (2012). Alkali activation of mortars containing different replacement levels of ground granulated blast furnace slag, Construction and Building Materials, 28, pp. 708-712.

[27]. Gao, T., Jelle, B. P., Gustavsen, A., Jacobsen, S. (2014). Aerogel-incorporated concrete: An experimental study, Construction and Building Materials, 52,130-136.
[28]. Woignier, T., Phalippou, J. (1988). Mechanical strength ofsilica aerogels, Journal of NonCrystalline Solids, 10, 404-408.

[29]. Júlio, M.F., Soares, A., Ilharco, L. M., Flores-Colen, I., de Bito, J. (2016). Silica-based aerogels as aggregates for cement-based thermal renders, Cement and Concrete Composites, 72, 309-318.

[30]. Bostanci, L., Ustundag, O., Sola, O. C., Uysal, M., (2020). ffect of curing methods and scrap tyre addition on properties of mortars, Gradevinar, 72, 4, 311-322.

[31]. Bostanci, L., Ustundag, O., Sola, O., Uysal, M., (2019). ffect of various curing methods and addition of silica aerogel on mortar properties, Građevinar, 71, 8, 651-661.

[32]. Hanif, A., Lu, Z., Cheng, Y., Diao, S., Li, Z. (2017). Effects of ifferent lightweight functional fillers for use in ementitious composites, International Journal of Concrete Structures and Materials, 11, 99-113.

[33]. Lu, J.-X. , Poon, C.S. (2018). Improvement of earlyage properties for glass-cement mortar by adding nanosilica, Cement and Concrete Composites, $\mathbf{8 9}$, 18-30.

[34]. Wyrzykowski, M., Kiesewetter, R., Kaufmann, J., Baumann, R., Lura, P. (2014). Pore structure of mortars with cellulose ether additions - Mercury intrusion porosimetry study, Cement and Concrete Composites, 53, 25-34. 